\title{
Patrimônio Cultural e escrita da história:a hipótese do documento na prática do Iphan nos anos 1980'
}

\section{Flávia Brito do Nascimento ${ }^{2}$}

RESUMO: Na década de 1980, técnicos do Instituto do Patrimônio Histórico e Artístico Nacional (Iphan) passaram a utilizar argumentos do campo disciplinar da história para justificar a seleção do patrimônio para além dos cânones da excepcionalidade. Mobilizando autores e conceitos da Escola dos Annales, justificavam tombamentos de conjuntos urbanos cujas características não se enquadravam nas narrativas de identidade nacional via colonial praticadas nas primeiras décadas da Instituição. Laguna/SC, Cuiabá/MS, Morro da Conceição e Praça XV de Novembro no Rio de Janeiro, por exemplo, serão preservados não somente pelo valor histórico das suas edificações, mas também pela sua potencialidade como fonte histórica. Elaboram-se, então, argumentos de preservação de bens imóveis que buscavam driblar os conceitos do aporte legal do Decreto-lei no 25/37, buscando proteger sítios e lugares por seu valor documental. $\bigcirc$ artigo discute as relações entre escrita da história e preservação do patrimônio cultural, tendo como foco o caso de Laguna/SC. Pretende-se compreender de que maneira a proteção legal foi justificada a partir do inédito entendimento da cidade como documento por meio do estudo do processo de tombamento, seus estudos técnicos e as mobilizações teóricas do campo da história social e de autores como Marc Bloch e Jacques Le Goff.

PALAVRAS-CHAVE: Laguna/SC. Escola dos Annales. Cidade como documento. Iphan.

ABSTRACT: In the 1980s, technicians from the Institute for National Artistic and Historical Heritage (lphan) began to look to the academic discipline of History for arguments to support the selection of heritage assets that went beyond the grandiose. Engaging actors and concepts from France's historiography they justified listing buildings and urban ensembles with characteristics that did not fit into the colonial-based national identity narratives used by the institution in its early decades. During this time, sites such as Laguna (in Santa Catarina State), Cuiabá (in Mato Grosso State), Morro da Conceição and XV de Novembro Square (in the City of Rio de Janeiro), among others, were preserved not only for the historical value of their buildings, but also for their potential as a source of history. New preservation rationales for immovable assets were developed; these sought to circumvent the concepts set out in the provisions of Decree-Law No.

\begin{abstract}
1. Este artigo é uma versão revista e ampliada do trabalho apresentado no III Encontro da Associação Nacional de Pesquisa em Arquitetura e Urbanismo, realizado em São Paulo em 2014.

2. Docente na graduação e pós-graduação da Faculdade de Arquitetura e Urbanismo (FAU) da Universidade de São Paulo (USP). Pesquisa financiada com recursos da Fundação de Amparo à Pesquisa do Estado de São Paulo (Fapesp).
\end{abstract}


3. Ao longo do trabalho utilizaremos o nome atual do Iphan, Instituto do Patrimônio Histórico e Artístico Nacional. A instituição teve diversos nomes: 1937-1946 - SPHAN, Serviço do Patrimônio Histórico e Artístico Nacional; 1946-1970 DPHAN, Departamento do Patrimônio Histórico e Artístico Nacional; 1970-1979 - Instituto do Patrimônio Histórico e Artístico Nacional; 1979-1981 - Secretaria do Patrimônio Histórico e Artístico Nacional ligada à Fundação Nacional Pró-memória; 1981-1989 - Subsecretaria do Patrimônio Histórico e Artístico Nacional; 1989-1994 - IBPC, Instituto Brasileiro do Patrimônio Cultural; 1994 ao presente - Iphan.

4. Para as biografias desses profissionais, ver Analucia Thompson,(2009). Para a listagem dos funcionários da seção técnica e dos representantes regionais do Iphan nos anos $1930 \mathrm{e}$ 1940, ver Márcia Chuva (2009, p.198).
25/37, striving instead to protect sites and places according to their documental value. This article aims to discuss the city as a document, retrieving the concepts of document from Social History and Brazilian historiographical practices in their relationship with the preservation of built heritage. We will seek to examine how cities and their architecture were treated as sources by the field of preservation in Brazil, as well as to understand the theoretical discourse and the authors mentioned herein, such as Marc Bloch and Jacques Le Goff, and the studies of the urban centers where such rationale was put to practice, most notably Laguna, in Santa Catarina.

KEYWORDS: Laguna/SC. Annales. City as document. Iphan.

Introdução: patrimônio cultural e operatividade da história

Em 1937, os intelectuais modernistas, baseados em concepções de arte, história, tradição e nação, criaram o conceito de patrimônio que se tornou hegemônico no Brasil por meio do Serviço do Patrimônio Histórico e Artístico Nacional (SPHAN), ${ }^{3}$ institucionalizado com o objetivo de proteger as obras de arte e a história do país. $\bigcirc$ patrimônio está ainda hoje marcado por suas concepções de identidade nacional amplamente ancoradas no período colonial, cuja essência máxima estaria representada em cidades como Ouro Preto, Paraty e Olinda.

Como está claro na grande fortuna crítica da trajetória inicial da instituição federal de preservação (FONSECA, 1997; CHUVA, 2009; RUBINO, 1991 ; GONÇALVES, 1996; MILLET, 1988), a opção pela arquitetura do período colonial ancora-se na noção do patrimônio como constituidor da nacionalidade. A arquitetura barroca erigida pelo colonizador português, buscada com afinco pelos técnicos do patrimônio e encontrada em diversos pontos do país unificava o território e conferia identidade ao Brasil. Márcia Chuva destaca como o patrimônio mineiro, colonial, tornou-se exemplo de "brasilidade" no contexto do projeto de nacionalização estado-novista. A relação entre tradição e modernidade é constituinte do ideário nacionalista dos anos 1920 e foi posteriormente instrumentalizada nas estratégias de ação varguistas. $\bigcirc$ Iphan foi uma das frentes abertas pelo Ministério da Educação e Saúde, a partir do estabelecimento de padrões artísticos e arquitetônicos, nos quais a produção colonial estava no topo da escala de valores (CHUVA, 2009, p. 63, 91).

$\bigcirc$ projeto de patrimônio nacional estabelecido no Iphan teve clara opção pela arquitetura. Eram os objetos do mundo edificado que representariam o passado brasileiro e o articulariam ao presente, ao Estado Novo. Os arquitetos foram a maioria dos profissionais envolvidos com a preservação; nos quadros iniciais da instituição constavam os arquitetos Lucio Costa, Alcides Rocha Miranda, Renato Soeiro, Paulo Thedim Barreto, Ayrton Carvalho, Edgard Jacintho, José de Souza Reis, Lucas Meyerhofer, Sílvio de Vasconcelos e Luiz Saia. ${ }^{4}$ 
A opção pela arquitetura e sua permanência ao longo das gerações futuras estavam articuladas à escrita da história da arquitetura e à sua produção de conhecimento. A profissionalização da arquitetura e o alargamento do campo de atuação que incluiu o patrimônio histórico aumentaram as pesquisas e o conhecimento sobre a arquitetura colonial. A demanda de trabalho estabelecida pelo Iphan levou a uma substanciosa produção de conhecimento, até então pouco sistêmica. Na "Academia Sphan", batizada por Mariza Veloso Santos (SANTOS, 1996), os intelectuais dos anos 1930 debruçaram-se no estudo das edificações setecentistas em todo o país. A noção do desconhecimento e da tarefa por fazer é corroborada por Lucio Costa no primeiro número da Revista do Patrimônio, publicada em 1937, no artigo "Documentação necessária":

A nossa antiga arquitetura ainda não foi convenientemente estudada. Se já existe alguma coisa sobre as principais igrejas e conventos - pouca coisa aliás, e girando, o mais das vezes, em torno da obra de Antonio Francisco Lisboa, cuja personalidade tem atraído, a justo título, as primeiras atenções -, com relação à arquitetura civil e particularmente à casa, nada ou quase nada, se fez. (COSTA, 1995, p. 457)

A escrita da história era pressuposto da atividade de preservação do patrimônio cultural no Brasil. Preservou-se aquilo que seria fonte da história ou prova documental da articulação identitária nacional. A arquitetura colonial e barroca era testemunho de épocas pregressas, às quais articulavam-se os conceitos e preceitos de constituição nacional. Ela era fonte de produção de conhecimento, institucionalizada nas práticas de preservação no Brasil e nos primeiros momentos de escrita da história da arquitetura. A preservação de certos exemplares garantiria o conhecimento do que se gostaria de escrever como história. Lançou-se mão do tombamento como recurso de afirmação da arquitetura, defendida como garantia da materialidade e prova de originalidade não só às gerações futuras, mas às ameaças do presente. Os tombamentos eram a prova final da vitória. 5 No caso dos arquitetos "modernos da repartição", fundadores das práticas de preservação no Brasil, a relação entre materialidade e escrita da história esteve lado a lado das justificativas por proteções legais dos bens selecionados. A história da arquitetura era operacionalizada também por meio das fontes (no caso bens culturais) disponibilizados às gerações futuras.

Como mostrou José Lira (2010), a ideia da história a serviço do projeto é anterior ao século XX e, historicamente, a crítica da arquitetura foi comumente operativa e atendeu a propósitos práticos. Desde os primeiros historiadores da arquitetura moderna, ainda nos anos 1920, que o caráter operativo da história se fez sentir. A geração de historiadores da arte de Nicolaus Pevsner, Kaufmann e, sobretudo, Siegfried Giedion imbuiu-se do projeto de provar a legitimidade histórica do movimento moderno através da construção de genealogias próprias e muito particulares. Para Tournikiotis, a tradição de estudos da história da arquitetura apoiados em propósitos práticos permaneceu até os anos 1950, quando as crescentes incertezas quanto ao movimento moderno botaram em
5. Ver a argumentação desenvolvida por Flávia Brito do Nascimento (2016, capítulo 2). 
6. Sobre a Carta de Veneza e seus conceitos, ver Beatriz Mugayar Kühl (2010).

7. Sobre a Carta de Veneza e o Brasil, ver Ana Lúcia Cerávolo (2013) questão as genealogias e interpretações propostas por Pevsner e Giedion, seguidos por Bruno Zevi e Benévolo, que assumiram o moderno como fato que precisava ser disseminado e confirmado (TOURNIKIOTIS, 1999).

Tal afirmação é pertinente para o caso brasileiro. Operação historiográfica e preservação das fontes de pesquisa eram faces da mesma atuação, uma vez que, inicialmente, a escrita da história se deu por personagens do campo da preservação (COSTA, 1995; SANTOS, 1996). A excepcionalidade dos bens culturais como potenciais fontes de pesquisa alinhava-se à historiografia, justificando-se mutuamente. Grosso modo, pode-se afirmar que, até a década de 1960, os bens culturais calcados na excepcionalidade e monumentalidade ditadas pelo Decreto-lei 25/37 foram, de certa forma, "suficientes" como fontes da história que se escrevia.

Do ponto de vista da preservação, o cenário começa a mudar a partir da década de 1960, quando novos parâmetros sobre o que valeria preservar às gerações futuras entram em cena. A escrita da história da arquitetura se verá numa encruzilhada da ampliação das fontes e mudanças no conceito de patrimônio. Como lidar com o quadro social de memória das práticas históricas de preservação no Brasil fincadas no colonial diante do alargamento de conceitos? São questionamentos e dificuldades que se arrastarão nas décadas de 1960 e 1970, e que terão nos tombamentos dos anos 1980, dos quais Laguna em Santa Catarina é exemplar, novos paradigmas.

"Arquitetura menor": desafios à atribuição de valor e à historiografia nos anos 1960 e 1970

Já é fartamente discutido pela bibliografia que a Carta de Veneza, de 1964, promulgada no II Congresso Internacional de Arquitetos e de Técnicos de Monumentos Históricos, postulará novo cânone de preservação. Ela será responsável por estabelecer parâmetros de alargamento do conceito de bem cultural. Os seus princípios são considerados ainda válidos, seguindo como referência o documento-base do Conselho Internacional de Monumentos e Sítios (Icomos) para a preservação de bens culturais. À Carta seguiram-se outros documentos que aprofundaram ou reinterpretaram seus conceitos para um contexto mais amplo ou tratando de temas por ela não contemplados, sempre tendo em vista o seu detalhamento. ${ }^{\circ}$

Tendo o Brasil como signatário, a Carta de Veneza foi, desde então, divulgada e conhecida por aqui. ${ }^{7}$ Estiveram presentes ao Encontro do lcomos em Veneza os arquitetos representantes do Instituto de Arquitetos do Brasil (IAB), Ícaro de Castro Mello, Flávio Silveira, Wladimir Alves de Souza e Gian Carlo Gasperini, que trataram de divulgar, ao menos no meio paulista, o resultado das discussões e o texto da Carta de Veneza ICONGRESSO INTERNACIONAL DE ARQUITETOS E TÉCNICOS EM MONUMENTOS HISTÓRICOS, 1964). No 
meio patrimonial, como pudemos mostrar em outra ocasião (NASCIMENTO, 2016a), desde os anos 1970, no contexto dos cursos de Conservação e Restauração de Monumentos e Conjuntos Urbanos que aconteceram em 1974 (São Paulo), 1976 (Recife) e 1978 (Belo Horizonte), ensinavam-se os preceitos da carta e se debatiam as suas implicações em face do Decreto-lei 25/37. As aulas do professor Augusto da Silva Telles, técnico do Iphan, tratavam da legislação e dos conceitos de ambiência urbana, arquitetura "menor" e o valor documental da cidade e da arquitetura (TELLES, 1976). Na ementa de sua disciplina Teoria da Conservação, no Curso de Especialização de 1976 em Recife, o item Carta de Veneza traz a seguinte explicação, reveladora do nível de conhecimento que se pretendia passar aos alunos:

Análise dos conceitos de monumento e de bem cultural - sua ambientação - a "mise-en-valeur" ou valorização - sua integração ao entorno em que se situa e o testemunho histórico que representa - estudo através das definições dos documentos internacionais/ regionais. (TELLES, 1976, grifos nossos)

Para a discussão da arquitetura e da cidade como fonte documental aqui problematizada, a Carta será muito importante. $\bigcirc$ valor patrimonial estaria presente não somente nos grandes monumentos, chamados de conjuntos arquitetônicos, mas também nas obras modestas, que, pela cultura e pelos processos históricos, passaram a ter valor de patrimônio. $\bigcirc$ valor testemunhal da arquitetura como documento da história será destacado na Carta de Veneza:

A noção de monumento compreende não só a criação arquitetônica isolada, mas também a moldura em que ela é inserida. $\bigcirc$ monumento é inseparável do meio onde se encontra situado e, bem assim, da história da qual é testemunho. Reconhece-se, consequentemente, um valor monumental tanto aos grandes conjuntos arquitetônicos, quanto às obras modestas que adquiriram, no decorrer do tempo, significação cultural e humana. (CARTA..., 2004)

conceito de "testemunho da história" validará as ações de preservação na esfera alargada do ambiente urbano. Todas as edificações teriam o direito de permanecer às gerações futuras, sejam monumentais, sejam modestas, na medida em que documentavam a história. Para Laurajane Smith, a Carta de Veneza é um dos textos fundacionais das práticas e dos movimentos de preservação nos anos 1960 em diante, formando a base filosófica dos processos técnicos de gerenciamento do patrimônio nas décadas seguintes. Mas, segundo a autora, o texto da carta não explica o que seria o valor das obras modestas, assumido de antemão pelos leitores e autores da carta, os especialistas. A ideia de monumento como testemunho do passado, explícita na Carta de Veneza, de alguma forma aprisiona a memória nos lugares, ajudando a legitimar e naturalizar o papel da conservação. Nela, os monumentos são imbuídos da mensagem do passado, "inseparáveis da história de que foram testemunho" (SMITH, 2006, p. 90-92).

No Brasil, conforme mencionamos, a Carta era conhecida desde sua promulgação em 1964. Parece-me que a Carta de Veneza e os ventos de 
transformação no pensamento patrimonial dos anos 1960 e 1970 levaram os historiadores da arquitetura no patrimônio nacional a um impasse. Ampliar o valor patrimonial e considerar como testemunhos do passado outras arquiteturas que não as coloniais e modernas (notadamente as excepcionais) talvez implicassem alterar a legislação nacional de preservação, o Decreto-lei 25/37. Esse decreto fundava seus princípios na nacionalidade, excepcionalidade e monumentalidade, essencialmente distante do que se compreenderá como patrimônio a partir de então. Além disso, diante das já mencionadas relações muito próximas entre historiografia da arquitetura, fontes primárias e preservação, implicaria revisões e novas visadas. Ou seja, a ampliação das fontes a partir da ideia de memória "aprisionada" nos lugares, como interpreta Laurajane Smith, levaria a novas escritas da história. Logo, a novas políticas de preservação.

Ao longo das duas décadas que se seguiram à Carta de Veneza, o Brasil esteve sob a ditadura civil-militar, instaurada também em 1964, mesmo ano da carta. O período será repleto de desafios, mudanças conceituais, políticas e práticas para o campo disciplinar da preservação no Brasil. Do papel fundamental dos consultores internacionais por meio da Unesco ao Programa de Cidades Históricas (PCH), gestado fora do Iphan como política de governo dos militares, a Instituição focará seus esforços na gestão e viabilidade econômica dos monumentos protegidos por lei (CORREA, 2012; NASCIMENTO; MARINS, 2016). As recomendações de ampliação do conceito de ambiência foram vividas pelos intelectuais da preservação do Iphan com dificuldade, uma vez que implicavam mudanças de significativa importância, questionadoras da "ortodoxia" do patrimônio, para usar a expressão de Marly Rodrigues (RODRIGUES, 2000). Uma das saídas foi o "transbordamento" de funções do Iphan com a criação de órgãos estaduais de preservação. Estes iriam compor o sistema de patrimônio no Brasil e atuar na atribuição de valor regional e nos interesses locais, a liviando a iá notória sobrecarga de trabalho do Iphan (CAMPOFIORITO, 1985).

No Iphan, vigorou até o final da década de 1960 o tombamento pelo valor artístico, representado pela existência de exemplares de grande valor ligrejas, fortes, sobrados), com predominância da arquitetura típica dos séculos XVII e XVIII, com urbanização da América Portuguesa. O município de lguape, no estado de São Paulo, por exemplo, teve na ocasião o pedido de tombamento negado por não corresponder aos critérios estético-estilísticos estabelecidos, tendo muitas construções com "alterações" do século XIX (NASCIMENTO; SCIFONI, 2015).

A pressão pela consideração de outras heranças culturais será absorvida de modo mais evidente na escala regional, como são os exemplos do município de São Paulo e sua aproximação com o planejamento urbano, do Instituto Estadual do Patrimônio Cultural (Inepac) do Rio de Janeiro e do Conselho de Defesa do Patrimônio Histórico Arqueológico, Artístico e Turístico (Condephaat) de São Paulo (ROCHA-PEIXOTO, 1990; CAMPOFIORITO, 1984; RODRIGUES, 2000). O compartilhamento de funções com outros órgãos de preservação de certa maneira poupou o Iphan, nesse momento, de novas atribuições de valor e 
estudos. Isso implicou que o lugar da escrita da história da arquitetura não era mais exclusivo do Iphan. A relação entre as fontes documentais como prova material e a operatividade do ato de preservação mudará de agentes.

Nos anos 1980, a redemocratização do Brasil dará novas perspectivas à preservação. Vive-se um boom do patrimônio cultural. Articulador de identidades, demandado pela sociedade civil como direito, o patrimônio urbano e as preexistências serão alvo de muito debate. A sociedade civil organizada questionará a atuação do Iphan em muitos casos, como no Rio de Janeiro, em que a tensão das perdas sucessivas de exemplares de valor cultural significativo será muito sentida. A pressão por novos reconhecimentos e a discussão sobre o papel do Iphan serão fundamentais nos anos seguintes. A resposta institucional em preservações, como as de Laguna em Santa Catarina, coloca o valor documental em primeiro plano, ajudando na argumentação para além dos critérios de excepcionalidade do Decreto-lei n.25/37.

A história no patrimônio e a revolução do documento

O ambiente da redemocratização na década de 1980 trouxe à tona os segmentos médios que lutavam por qualidade de vida e tomaram o patrimônio como bandeira - os quais, somados às minorias e aos grupos étnicos, levaram à proteção de novos objetos. A redemocratização política, a crise financeira e a falência do modelo de desenvolvimento nublaram ou tornaram menos importantes, em caráter momentâneo, as políticas de aproveitamento turístico e econômico do patrimônio dos anos 1970, cujo Programa de Cidades Históricas foi a maior vitrine (SANT'ANNA, 2004, p. 29, 96). Todas estas ajudaram a colocar a ideia do testemunho histórico e dos processos sociais na linha de frente das argumentações possíveis à preservação.

De acordo com Márcia Chuva (CHUVA, 2008), novos enfoques conceituais e metodológicos dos anos 1980 abriram espaço para mudanças que estão ligadas a dois aspectos fundamentais: o novo papel do Estado e a inclusão de outras esferas do Poder Público, fruto de novos de interesses e de setores da sociedade civil organizada, e a ampliação da noção de patrimônio, atingindo leque mais amplo e diversificado de bens para muito além da perspectiva da identidade nacional unívoca. Nesse borbulhar de transformações, onde de bondes a pedras, de mercados a terreiros de candomblé, tudo era patrimônio, é que os desafios metodológicos do campo disciplinar se fizeram sentir de maneira contundente.

Como finalmente, após quase vinte anos, incorporar no âmbito das práticas seletivas do patrimônio cultural do Iphan os conceitos da Carta de Veneza e o valor testemunhal dos bens imóveis? Parece-nos que o compartilhamento das atribuições de seleção, proteção e promoção do patrimônio no Brasil organizado na década de 1970, da forma como foi estruturado, em muitos casos, à semelhança da legislação federal, criava dificuldades no partilhar de 
8. Sobre o Inepac, ver Ítalo Campofiorito (1984) e, sobre o Condephaat, Marly Rodrigues (2000). atribuições, não estando muitas vezes claros os chamados valores locais e nacionais. O Iphan centrou seus esforços para firmar-se como o detentor intelectual dos saberes e fazeres da preservação no Brasil, cumprindo o papel de liderar projetos. Mesmo naqueles em que estivera inicialmente excluído, como no Programa das Cidades Históricas, foi pouco a pouco assumindo lugar destacado (CORREA, 2012; NASCIMENTO, 2016a). Salvo exceções citadas anteriormente, as novas demandas por seleção de bens culturais para os livros do tombo eram frequentemente repassadas aos órgãos locais. Voltando ao exemplo de lguape, no estado de São Paulo, a cidade foi tombada pelo Condephaat por intermédio do Iphan que, recebendo o pedido de preservação, repassou-o ao órgão estadual (INSTITUTO..., 2009). Nos primeiros anos da década de 1980, os órgãos regionais de patrimônio, como o Condephaat de São Paulo e o Inepac do Rio de Janeiro, estruturaram sua atuação calcados nas demandas da sociedade civil organizada, aproximando-se do patrimônio como promotor de identidades e distanciando-se dos discursos da nacionalidade. ${ }^{8}$ Muito embora, como bem estudou Lia Motta, eles rompessem apenas parcialmente com as narrativas oficiais na medida em que seguiam estruturando-se a partir da linha do tempo da arquitetura, recompondo as lacunas, como o ecletismo, sem que se mudasse $o$ enfoque do patrimônio como algo socialmente atribuído e partilhado, para além dos saberes técnicos (MOTTA, 2000a).

De toda forma, o Iphan, no processo de atribuição de valor aos bens culturais nos anos 1970, via-se imerso nas dificuldades de selecionar bens para além dos cânones do "belo e do velho" para romper com as arramas de um patrimônio entendido como nacional. Na história institucional do patrimônio nacional, é bom lembrar que havia uma hierarquia de valores, sendo os artísticos os mais importantes. Os bens imóveis considerados de maior relevância eram inscritos no Livro das Belas-Artes como demonstração de seu valor, conforme já apontado por Silvana Rubino. Os saberes técnicos dos arquitetos ditaram historicamente as regras de preservação (RUBINO, 1996).

Na década de 1980, além das demandas da sociedade civil em favor do patrimônio cultural como direito levando à ampliação e diversificação de atuação, houve um deslocamento de conceitos no Iphan, que redundará em novo pensamento sobre o documento material e a sua relação com a preservação. Os aportes teóricos da história social serão apropriados em tombamentos de centros históricos diversos. Centros urbanos foram selecionados como patrimônio a partir da argumentação do testemunho como seu primeiro valor. Mais importante: não é o testemunho no sentido da prova documental da história nacional que se narrava, mas, sim, como fonte documental da história passível de interpretação, questionamento, perguntas e problematização pelo historiador, valendo-se da tradição historiográfica francesa de pesquisadores reunidos em torno da Revista dos Annales.

Desde o final dos anos 1920 que a noção de documento estava em questão no campo disciplinar da história. Proposta pelos historiadores dos 
Annales, como Marc Bloch e Lucien Febvre, organizados em torno da revista fundada em 1929, balizou o ofício do historiador durante o século XX. Na base das transformações propostas pelo grupo dos Annales estava o questionamento aos documentos e a utilização de novas abordagens no seu uso. Contrapondo-se à história positivista do século XIX, calcada no documento textual como fonte de verdade e de fatos, tais historiadores buscavam uma visão problematizadora da história. Com o aporte de outras áreas das ciências sociais, construíram a "história-problema" em oposição à história narrativa factual, em que os eventos se sucediam num encadeamento cronológico e muitas vezes biográfico. Tratavase da história cientificista, investida de objetividade, fundada na suposta verdade documental, muitas vezes esvaziada de conceitos que norteavam a produção historiográfica. Na "história-problema", as hipóteses e perguntas eram colocadas antes dos fatos e dos acontecimentos, destacando-se, com isso, a construção historiográfica (REIS, 2010, p. 96-97).

Ao retirar a possibilidade de extrair a suposta verdade dos documentos textuais, investidos da aura de autenticidade, os historiadores dos Annales se colocavam diante do desafio intrínseco à sua visão da escrita da história, que é o do trato com as fontes. $\bigcirc$ uso das fontes exclusivamente documentais limitara a compreensão e consequentemente a leitura dos outros dados que frequentemente escapavam ao historiador, como, por exemplo, dados estatísticos, jurídicos e econômicos. A história que propõem será associada ao uso de documentos variados, que ajudariam nas "respostas" às perguntas formuladas pela problematização inicial. Os documentos eram de ordem variada, organizados, portanto, conforme as necessidades da pesquisa. Tudo que pertenceria ao homem e demonstrasse suas atividades, gostos e maneiras de ser interessaria ao historiador, conforme Lucien Febvre, no célebre livro Combates pela História:

A História faz-se com documentos escritos, sem dúvida. Quando estes existem. Mas ela pode fazer-se, ela deve fazer-se sem documentos escritos, se os não houver. Com tudo o que o engenho do historiador pode permitir-he utilizar para fabricar o seu mel, à falta das flores habituais. Portanto, com palavras. Com signos. Com paisagens e telhas. Com formas de cultivo e ervas daninhas. Com eclipses da lua e cangas dos bois. Com exames de pedras por geólogos e análises de espadas de metais por químicos. Numa palavra, com tudo aquilo que, pertencendo ao homem, depende do homem, serve o homem, exprime o homem, significa a presença, a atividade, os gostos e as maneiras de ser do homem. (FEBVRE, 1989, p. 249)

Para Marc Bloch (BLOCH, 2001), fundador dos Annales, o conhecimento do historiador é sempre produzido com vestígios, documentos incompletos de fenômenos, em si, impossíveis de captar. $\bigcirc$ que se tem acesso no presente é um fragmento do passado. E tais testemunhos são extremamente diversos, quase infinitos. Tudo o que o homem escreve, fabrica e toca serve para informar sobre ele. A pesquisa histórica deve levar em consideração uma multiplicidade de documentos e testemunhos para se realizar. Não haveria, portanto, um único documento para um único problema. A exaustiva tarefa de 
9. O tema é tratado por autores diversos que investigaram a produção historiográfica nacional e suas diretrizes teóricas, tais como Márcia D’Alessio (1994), Marieta Ferreira (2013), Diogo Roiz; Rafael Santos (2012), Maria Helena Capelato et al (1994). reunir bases documentais, compreender suas lógicas próprias e verificar as ausências seria o primeiro esforço do historiador para a construção de problemas para a pesquisa. $O$ trato com fontes diversas era uma premissa da históriaproblema, construída como método crítico.

O alargamento das bases documentais anunciado desde a geração fundadora dos Annales levou ao que se nomeou "revolução documental", que aconteceria a partir dos anos 1960. Jacques Le Goff, no texto Documento/ Monumento escrito para a Enciclopedia Einaudi no final dos anos 1970, esclarece que a mudança no trato com os documentos foi ao mesmo tempo quantitativa e qualitativa. A história se interessaria por todos os homens e seus vestígios, desde que guiada pela crítica ao documento e aos problemas postos diante dos mesmos (REIS, 2010).

O conhecimento dos historiadores dos Annales no Brasil e de suas propostas metodológicas teve longo alcance. ${ }^{9}$ Em São Paulo, os cursos de História e Geografia da Universidade de São Paulo (USP) foram fundados por franceses, e desde os anos 1930 a discussão da história-problema focada nos aspectos econômicos e sociais de alguma forma circulava. A presença de um de seus protagonistas, Fernand Braudel, como docente na USP por quase dois anos garantiu intercâmbios recorrentes entre Brasil e França e uma "tradição francesa" no seu perfil acadêmico até os anos 1970. A ideia do documento a serviço do problema e das perguntas que o historiador elabora conviveu com a perspectiva do marxismo; juntas elas informaram a produção historiográfica na USP dos anos 1950, 1960 e 1970 (D'ALESSIO, 1994).

No Rio de Janeiro, a tradição francesa também foi importante, a partir de professores que também vieram para ministrar cursos na Universidade do Distrito Federal e na Faculdade Nacional de Filosofia. No entanto, para Marieta Ferreira, deve-se matizar a influência dos historiadores dos Annales, tanto no Rio de Janeiro como em São Paulo, frente ao perfil muito variado de docentes também da França, que vieram para o Brasil ministrar cursos na década de 1930 em diante. Havia tanto professores que partilhavam dos preceitos da história econômica e social como aqueles focados nos grandes eventos e na narrativa. De modo geral, vieram para o Rio de Janeiro professores mais velhos e titulados e para São Paulo professores mais jovens, em início de carreira, como o próprio Fernand Braudel. Para a historiadora, a influência dos franceses foi limitada no que se refere ao modo de fazer história no Brasil, embora fundamental na estruturação dos cursos, renovação bibliográfica e desenvolvimento de intercâmbios entre os países (FERREIRA, 2013, p. 99-101).

Para este estudo, interessa saber que nos anos 1980 autores como Bloch, Febvre, Braudel e Labrousse eram amplamente conhecidos no meio da história, citados em dissertações e teses (D'ALESSIO, 1994). A partir de então, a redemocratização trouxe novos temas para o debate historiográfico, como cidadania, movimentos sociais, operariado e cultura, apresentando um leque muito ampliado de possibilidades para os pesquisadores. A "Nova História 
Cultural", estruturada a partir do que se chamou por terceira geração dos Annales, teve relativa demora em ser aceita e conhecida, porém foi divulgada amplamente nos anos 1980 (ROIZ; SANTOS, 2012). ${ }^{10}$

De que maneira os autores dos Annales e suas reflexões chegaram ao campo da preservação brasileira? $\bigcirc$ arquiteto Luiz Fernando Franco terá papel decisivo nesse processo. Formado em Arquitetura pela Universidade de Florença em 1972, passou as décadas de 1960 e 1970 na Europa como estudante de graduação e depois de pós-graduação na França (Universidade de Aix-Marseille, Institut d'Amenagement du Territoire) e trabalhando depois como profissional. Retornou ao Brasil na primeira metade da década de 1980 e passou a trabalhar na Diretoria de Estudos e Tombamentos (DET) do Iphan, no Rio de Janeiro. Os livros dos historiadores dos Annales foram trazidos da França e o aprofundamento de seus conceitos aconteceu já no Rio de Janeiro. " A historiadora Márcia Chuva foi estagiária na DET no momento em que os estudos para o tombamento de Laguna estavam em elaboração. Segundo sua informação, o ambiente de estudo e de busca por novos conceitos era bastante efervescente. A equipe envolvida fazia grupos de estudos e discutia autores da história e também da arquitetura, como o italiano Gianfranco Cannigia, apresentado e traduzido por Luiz Fernando Franco. ${ }^{12}$

ambiente institucional naquele momento, e também nos demais órgãos estaduais de patrimônio, era de ampliação da atuação, no entendimento do patrimônio, para além do "belo e do velho". A citação de Aloísio Magalhães, presidente do Iphan entre 1979 e 1981, é emblemática do ambiente intelectual da época:

Assim, meus caros amigos, o que se percebe é que o conceito de bem cultural extrapola a dimensão elitista, de "o belo e o velho", e entra numa faixa mais importante da compreensão como manifestação geral de uma cultura. $\bigcirc$ gesto, o hábito, a maneira de ser da nossa comunidade se constituem no nosso patrimônio cultural. (MAGALHÃES, 1985, p. 63)

Nesse ambiente, a outrora "academia SPHAN" se vê desafiada a produzir conhecimento diante da demanda por novas atribuições de valor a objetos para além "do belo e do velho". Buscará, a partir da esfera da cultura, estudar o sistema de representações contidas nos objetos. Interessados em novos aportes conceituais, os técnicos do patrimônio cultural os encontram nos autores da historiografia francesa. A possibilidade de entender os bens culturais, especificamente os centros históricos, como fontes documentais viabilizou, a nosso ver, a proteção de bens imóveis que dificilmente encontrariam possibilidade de preservação nos conceitos da excepcionalidade determinada pela legislação federal de tombamento.

Os "historiadores do patrimônio" buscavam ultrapassar a noção de excepcionalidade para a valorização da história processual, numa perspectiva historiográfica bastante renovada para o campo da preservação no Brasil (CHUVA, 2008, p. 39). A argumentação do documento histórico, em contrapartida à tradicional noção de monumento isolado (tal como tratado pelo Iphan desde sua fundação), foi cada vez mais utilizada para justificar a seleção
10. Para a interpretação sobre as gerações dos Annales e suas vertentes, ver Peter Burke (1997).

11. Currículo de Luiz Fernando Franco e informações fornecidas por Maria Pace Chiavari, a quem agradeço a gentileza.

12. Informações fornecidas por Márcia Chuva, a quem agradeço. 
13. Basta lembrar que Lucio Costa, no documento que estabelece um Plano de Trabalho para a Divisão de Estudos e Tombamento da DPHAN, afirma que "não é necessário nem talvez mesmo aconselhável o recurso exclusivo a historiadores de profissão, uma vez que a curiosidade do ofício os conduz insensivelmente a pesquisas laterais demoradas e absorventes com prejuízo dos informes simples e precisos que interessam à repartição." In: José Pessôa (1999. p. 87). de bens fora do escopo da ancianidade ou das belas-artes. $\bigcirc$ caso mais emblemático e inaugural será o estudo de tombamento de Laguna, no estado de Santa Catarina, cujo parecer técnico é de Luiz Fernando Franco. $\bigcirc$ estudo de Laguna trará para o campo da preservação a discussão fundamental da história social que tinha no documento um de seus cernes. Uma mudança significativa de perspectiva para a tradição de arquitetos do patrimônio. ${ }^{13}$

A hipótese do documento como pressuposto de seleção implicou no aumento das áreas urbanas protegidas pelo Iphan. $\bigcirc$ alargamento de conceitos complexificava os desdobramentos práticos, sobretudo quanto aos critérios seletivos. Dada a importância do reconhecimento de bens edificados representativos da história da cidade, da arquitetura ou simplesmente dos processos históricos, sem fixar-se em parâmetros estéticos, recaía-se no problema de como justificar a seleção de certos bens diante da gama de possíveis imóveis preserváveis. $\bigcirc$ interesse da comunidade nem sempre bastou e, em muitos casos, seguiu-se recorrendo à história ou à arquitetura, não obstante tratar-se de "novas histórias", como a eclética.

A ideia da cidade como documento de um dado processo social e histórico será muito diferente daquela da cidade que representa a nação e emana seus valores de unidade e identidade, constitutiva do Iphan desde os anos 1930. A mudança na prática preservacionista nacional dos anos 1980, ainda que possa se considerar sua limitação frente aos desafios, trouxe o valor documental para o primeiro plano como justificativa de preservação. E veio como possibilidade de escrita da história, na medida em que preservou documentos para as gerações futuras escreverem-na.

Vale lembrar que o valor testemunhal não era, no entanto, novidade na história da preservação. A cidade como documento e materialização da história era um atributo já estabelecido nas práticas de preservação pelo Ocidente a partir do século XIX. Françoise Choay nos mostra que a ideia de preservação da cidade como objeto de conhecimento foi motivada pelas mudanças traumáticas do ambiente urbano após a Revolução Industrial. O conhecimento da cidade do passado, seja para destruí-la, seja para preservá-la, levará à sua compreensão sob pontos de vista distintos. Para além do monumento ou objeto isolado, a "invenção do patrimônio urbano" permitirá o olhar para a cidade como identidade, conhecimento ou história (CHOAY, 2001, Capítulo 5).

No Brasil, a necessidade de compreensão mais ampla de patrimônio ampliará a noção monumento. A ideia dos artefatos materiais como documentos históricos surgiu, na década de 1980, como uma possibilidade de argumentação. Mas de que maneira a história foi mobilizada nesses processos de preservação e qual a relação com o tema epistemológico das fontes documentais na história são questões que nos interessam problematizar a seguir. Como o alargamento da noção de documento chega à arquitetura, permitindo entendê-la como vestígio material a ser preservado? Quais aportes teóricos que aparecem nas argumentações de preservação que se aproximam da noção de documento proposta pelos Annales? 
estudo de tombamento da cidade de Laguna pode ser considerado o ponto de inflexão nas práticas de preservação dos anos da redemocratização (SANT'ANNA, 1995; MOTTA, 2000a). As argumentações mobilizadas em favor da preservação de uma cidade em que os processos sociais e econômicos estavam presentes no seu espaço construído trouxeram novidades para o campo, dentre as quais, o uso das argumentações da história. Em Laguna, os bens imóveis da cidade foram olhados como conjunto e não como somatório de edificações de valor arquitetônico.

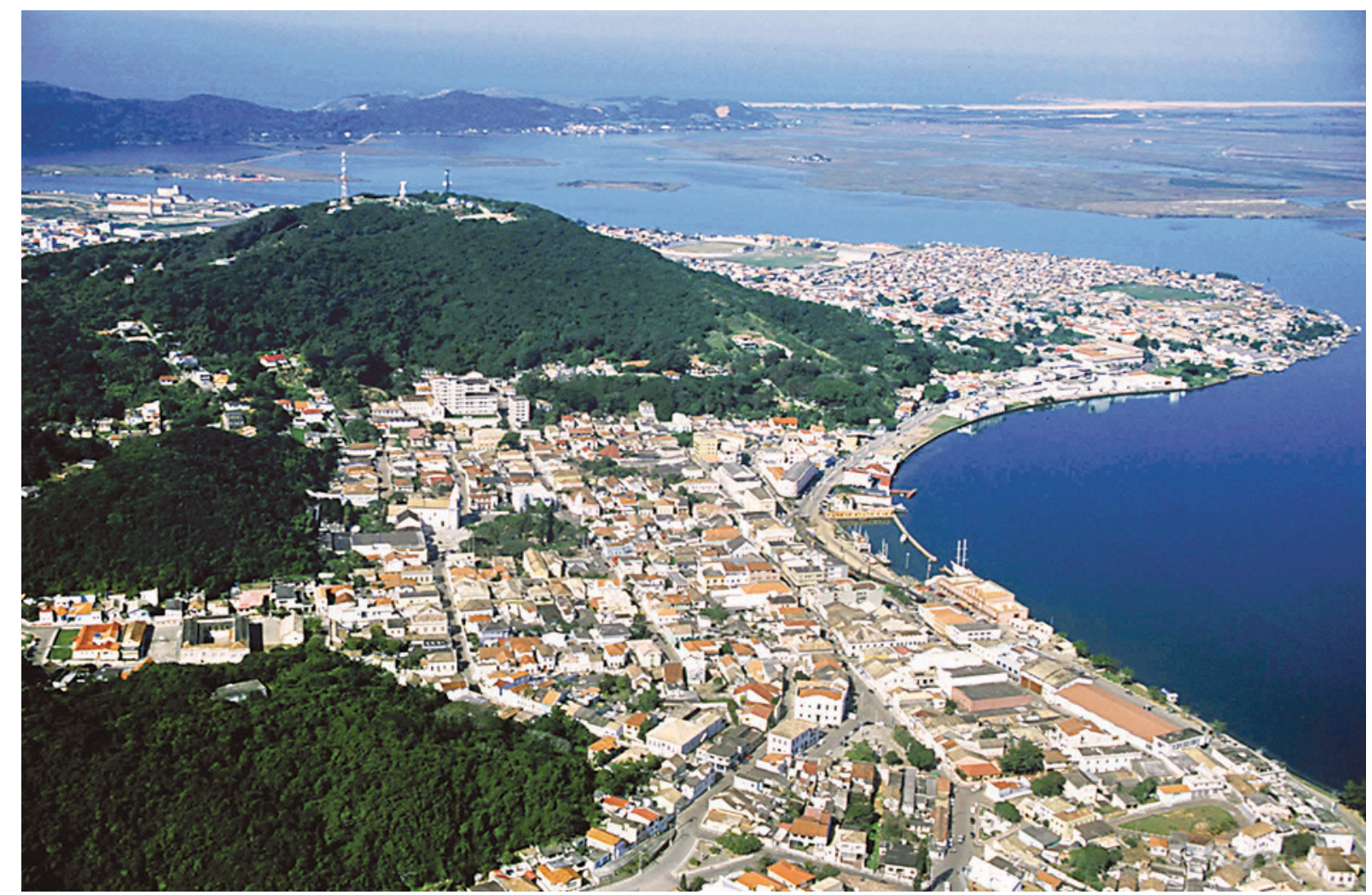

Figura 1: Vista aérea do Centro Histórico de Laguna/SC. Fonte: Acervo da Superintendência do Iphan em Santa Catarina.

processo de tombamento de Laguna foi aberto em abril de 1984, após o pedido do prefeito da cidade, João Gualberto Pereira, ao Iphan. A solicitação tinha caráter de urgência. Um decreto municipal proibia por noventa dias demolições de imóveis na sua área central, e o prefeito, diante das "grandes dificuldades de arcar com tais problemas", solicita a ajuda ao "Patrimônio Nacional". O veemente pedido afirmava que, após o prazo de 90 dias, seria "dificílimo manter a integridade do centro de Laguna". A ajuda do patrimônio 
14. Publicado também em Instituto.., Estudos de tombamento (1995). nacional era imprescindível. A cidade vinha assistindo ao desaparecimento de edificações históricas importantes, sofrendo inúmeras pressões para a construção de novos edifícios. Dois anos antes, em 1982, um dos prédios icônicos da arquitetura lagunense havia sido demolido num prazo quatro horas, sem que nada pudesse ser feito. E as pressões por transformação seguiam, sem que o Executivo municipal pudesse reagir (INSTITUTO..., 1984f, p. 7).

Diante do pedido, Julio Curtis, diretor da então $10^{a}$ Diretoria Regional, sediada em Porto Alegre, envia um telegrama a Augusto da Silva Telles, Diretor da Divisão de Tombamento e Conservação do Iphan:

Solicito Vossa Senhoria urgência decisão sobre tombamento provisório Centro Histórico de Laguna cuja Prefeitura mostra-se impotente deter processo rápido descaracterização. (INSTITUTO..., 1984k, p. 9l

As pressões para a preservação de Laguna chegam a Brasília oriundas de diversos lugares. Um telegrama vindo do reitor da Universidade Federal de Santa Catarina, o professor Joaquim da Luz, segue a Brasília para o secretário de Cultura do MEC, prof. Marcos Villaça, solicitando providências urgentes (INSTITUTO..., 1984j, p. 10). No dia 2 de julho de 1984, a pouco menos de trinta dias de terminar o prazo de proibição de demolições em Laguna, o prefeito escreve uma carta à secretária da Educação, Esther Figueiredo Ferraz, solicitando providências ainda mais urgentes, pois expirado o prazo, "dificílimo seria manter a integridade do centro de Laguna" (INSTITUTO..., 1984h). Em 6 de agosto de 1984, Augusto da Silva Telles escreve ao prefeito dando ciência da abertura do processo de tombamento, e explicando que o estudo requeria tempo para uma definição precisa da área e dos seus graus de proteção. Sugere a prorrogação do decreto municipal por mais 60 dias (INSTITUTO..., 1984e, p. 17).

No momento em que a carta de Silva Telles é enviada do Rio de Janeiro ao prefeito de Laguna, o caso já estava sendo estudado na "área central" do lphan (INSTITUTO..., 1984d, p. 14). No mês anterior, em julho de 1984, Luiz Fernando Franco vai a Laguna estudar a cidade. Pouco mais de um mês de depois, em 19 de setembro de 1984, o parecer de tombamento do arquiteto Luiz Fernando Franco é enviado a Dora Alcântara, coordenadora da Divisão de Tombamento e Conservação do lphan (INSTITUTO..., 1984c, p. 19-32; 19951. ${ }^{14}$ No final do mês de novembro daquele ano, o Conselho Consultivo reuniu-se em Curitiba e tombou o centro histórico de Laguna, de acordo com as recomendações do setor técnico do Iphan. A reunião do Conselho Consultivo foi realizada no Salão Nobre do Museu Paranaense, em Curitiba, a quarta vez que se reunia fora do Rio de Janeiro. A sessão pública, acompanhada por autoridades do Paraná, analisou os pedidos de preservação de bens culturais da região Sul: Museu do Mate (Campo Largo), Teatro São João (Lapa), Coleção Arqueológica João Alfredo Rohr (Florianópolis) e Centro Histórico de Laguna, relatado pelo conselheiro Alcídio Mafra de Souza, todos aprovados por unanimidade (INSTITUTO..., 1984a). 
Para a inscrição do "Centro Histórico da Cidade de Laguna" no Livro do Tombo Arqueológico, Etnográfico e Paisagístico, a instituição teve de agir com celeridade. Em rápido período de tempo, o arquiteto Luiz Fernando Franco organizou argumentação contundente e persuasiva o suficiente para justificar a proteção de núcleo urbano que até aquele momento não havia se configurado como de interesse à instituição. $\bigcirc$ arquiteto inicia o memorando lembrando que a cidade não tinha excepcionalidade, um pressuposto do Decreto-lei n. 25/37, cristalizado como prática e como quadro de memória nas práticas de preservação no Brasil. E dentre as edificações existentes de valor excepcional ele não saberia destacar outra que não fosse a Casa de Câmara e Cadeia, já tombada em 1953.

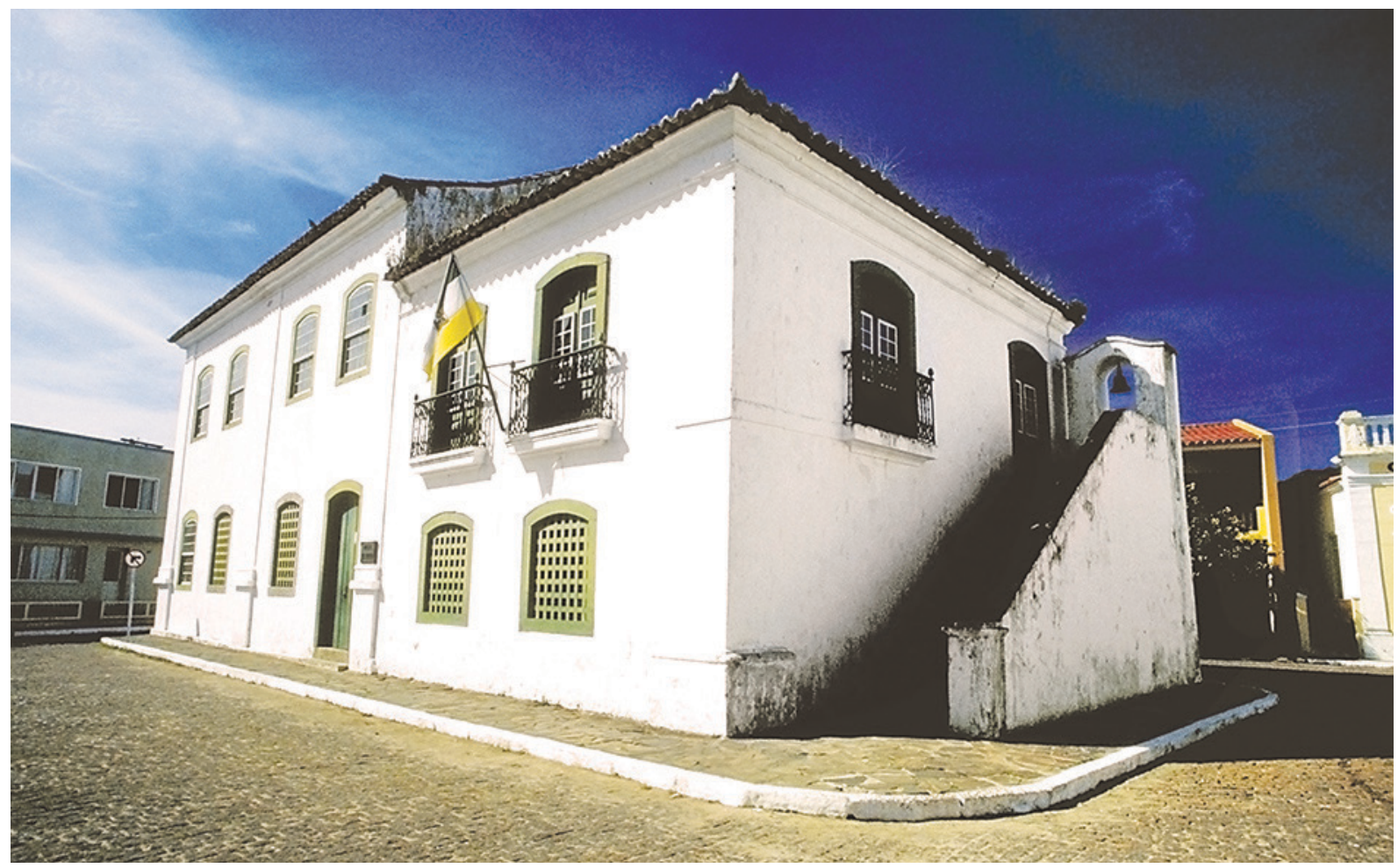

Figura 2: Casa de Câmara e Cadeia de Laguna/SC, tombada pelo Iphan. Fonte: Acervo da Superintendência do Iphan em Santa Catarina.

Ou seja, pelos critérios já conhecidos de monumento e nação, não havia o que argumentar em favor da preservação. Franco organiza sua argumentação a partir das premissas da legislação do Iphan, anunciando que o seu ponto de vista será diverso: a cidade era um documento precioso da história urbana do país ainda por ser contada. E inicia o documento, numa citação já bastante reproduzida que sintetiza os argumentos do estudo e da proposta de acautelamento:

Em sua dimensão estritamente arquitetônica, o patrimônio construído do centro histórico de Laguna não apresenta as características de excepcionalidade normalmente adotadas como 
critério para decidir sobre a oportunidade do tombamento. [...] Cremos, não obstante, tratar-se de documento precioso da história urbana do país, menos como sede de acontecimentos notáveis e embora estes tenham sido ali assinalados - do que pela escolha criteriosa do sítio; pelo papel que o povoado pode desempenhar, em virtude da sua localização, no processo de expansão das fronteiras meridionais; e sobretudo pela forma urbana assumida afinal como precipitação espacial dos dois processos precedentes. (INSTITUTO..., 1984c)

O diálogo com o Decreto-lei n. 25/37 e seus cânones está colocado. E talvez também está posto um diálogo com interlocutores possíveis que ainda sustentavam conceitos do decreto na década de 1980. $\bigcirc$ autor parece anunciar a conversa e apontar as dificuldades que terá (ou já teve) diante das exigências por excepcionalidade e representação da nação. $\bigcirc$ interesse do autor não era pelos eventos notáveis que pudessem ter ocorrido ali, mas sim para forma com a qual a área urbana da cidade poderia contar os processos de ocupação do território brasileiro, mais especificamente na expansão das fronteiras meridionais. Apresentando a variedade dos tempos históricos proposta por Braudel, alerta o leitor para a tentação de ordenar cronologicamente os bens culturais, dando-thes "ilusão de ordem e ritmo de fatos".

Interessava ao Iphan preservar Laguna não pela arquitetura, mas pela história. Mas certa história, não a factual, da sucessão de acontecimentos da qual a arquitetura poderia ser a prova material. E menos ainda a da história da arquitetura reificada, justificada nela mesma. A cidade poderia ser um documento para contar a história dos processos de fora "historiografia factual", dos eventos, que em certos espaços e tempos se transformavam em "desertos processos culturais longínquos no espaço econômico, social ou geográfico", aqui fazendo uma citação devidamente explicitada a Marc Bloch e a sua "Apologia da História". Importante ter em conta que, no processo de tombamento, logo após parecer técnico que propõe o tombamento de Laguna, vem um texto da então estagiária de história, Márcia Chuva, que apresenta uma "Avaliação Histórica" da cidade. Este nos parece um movimento inédito nos lugares de autoridade técnica no interior da instituição, demonstrativo dos diálogos interdisciplinares em curso. Os estudos técnicos para tombamento de bens imóveis eram frequentemente realizados tão somente por arquitetos a partir de argumentações da arquitetura. $\bigcirc$ estudo de Márcia Chuva sobre a "sociedade sulina" reforça os argumentos da história e reitera o pensamento de Fernando Franco de que a região Sul esteve à margem dos processos econômicos do período colonial, mas, não por isso, deixou de ter papel importante (INSTITUTO..., 1984b, p. 43-51).

É a partir desse lugar da cidade de Laguna como externa aos acontecimentos da América Portuguesa, naquele momento ainda pouco estudados e conhecidos, é que se justificava a sua preservação como documento pelo Iphan:

Este é o sentido "menor" do documento representado por Laguna, cuja preservação se legitima pela especificidade do processo de ocupação dos territórios meridionais e pela exigência de seu estudo. (INSTITUTO..., 1984c) 
A interação com a Carta de Veneza e o documento "menor" lque aparece no texto de Fernando Franco sempre entre aspas) está posta. A Carta de 1964 havia estabelecido que o valor testemunhal estava em potencial em todos os vestígios da produção humana, ampliando largamente a possibilidade de seleção e preservação. E se Carta não explicita o valor do menor (SMITH, 2006), o arquiteto do Iphan o faz de maneira instigante, ajudando a justificar sua preservação. Valendo-se de Walter Benjamin, lembra que nenhum fato é histórico, torna-se histórico com o tempo, posteriormente a ele, às vezes depois de séculos. A preservação deve estar consciente da mutabilidade histórica dos valores como ato de cultura e atenta para a sua transformação conforme o tempo e o lugar. Laguna era documento menor diante do quadro ainda pouco conhecido da ocupação do território na América Portuguesa.

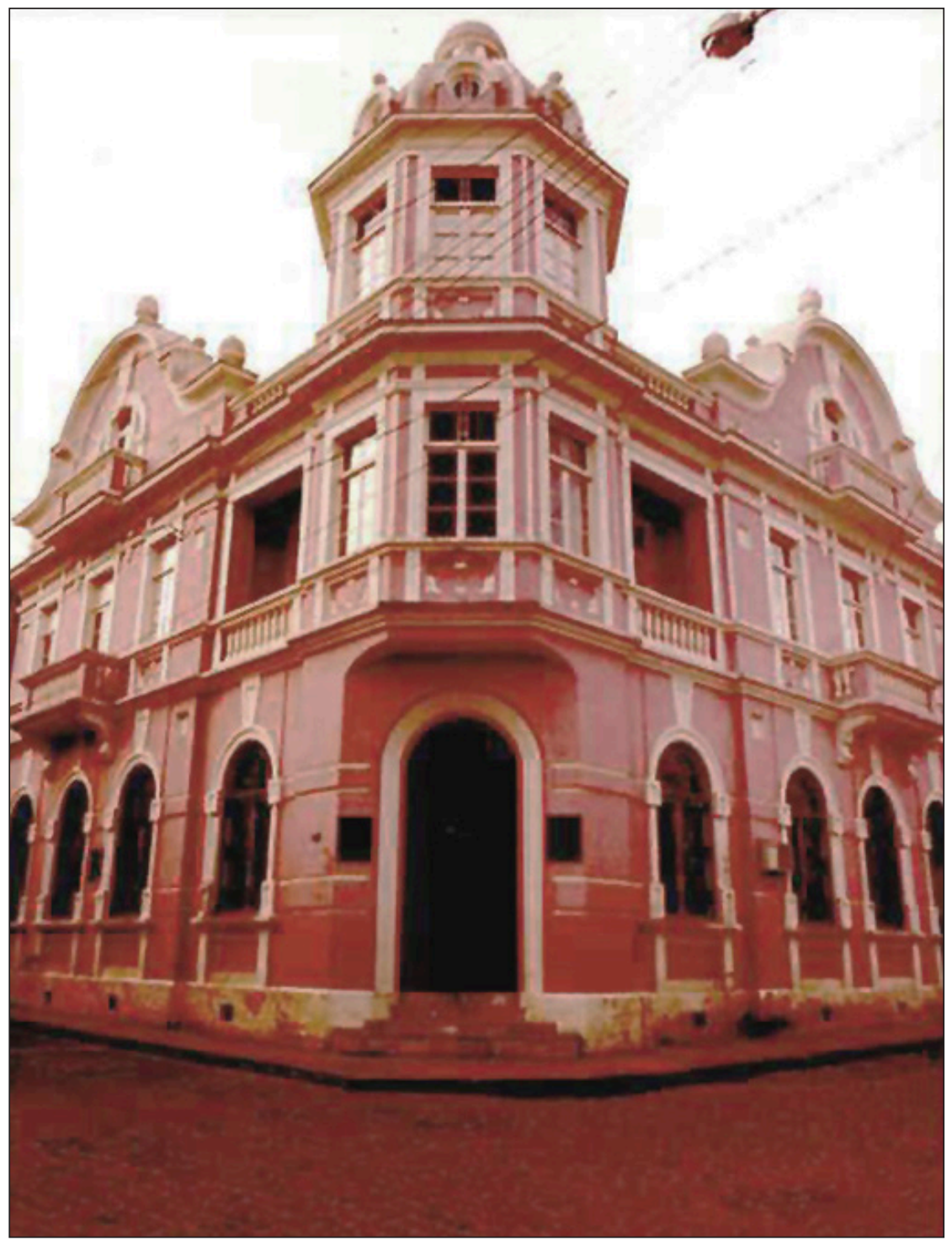

Figura 3: Aspectos da arquitetura do Centro Histórico de Laguna à época do tombamento federal. Fonte: Iphan (1984). Apenso II do Processo de Tombamento n. $1122-T-84$ 

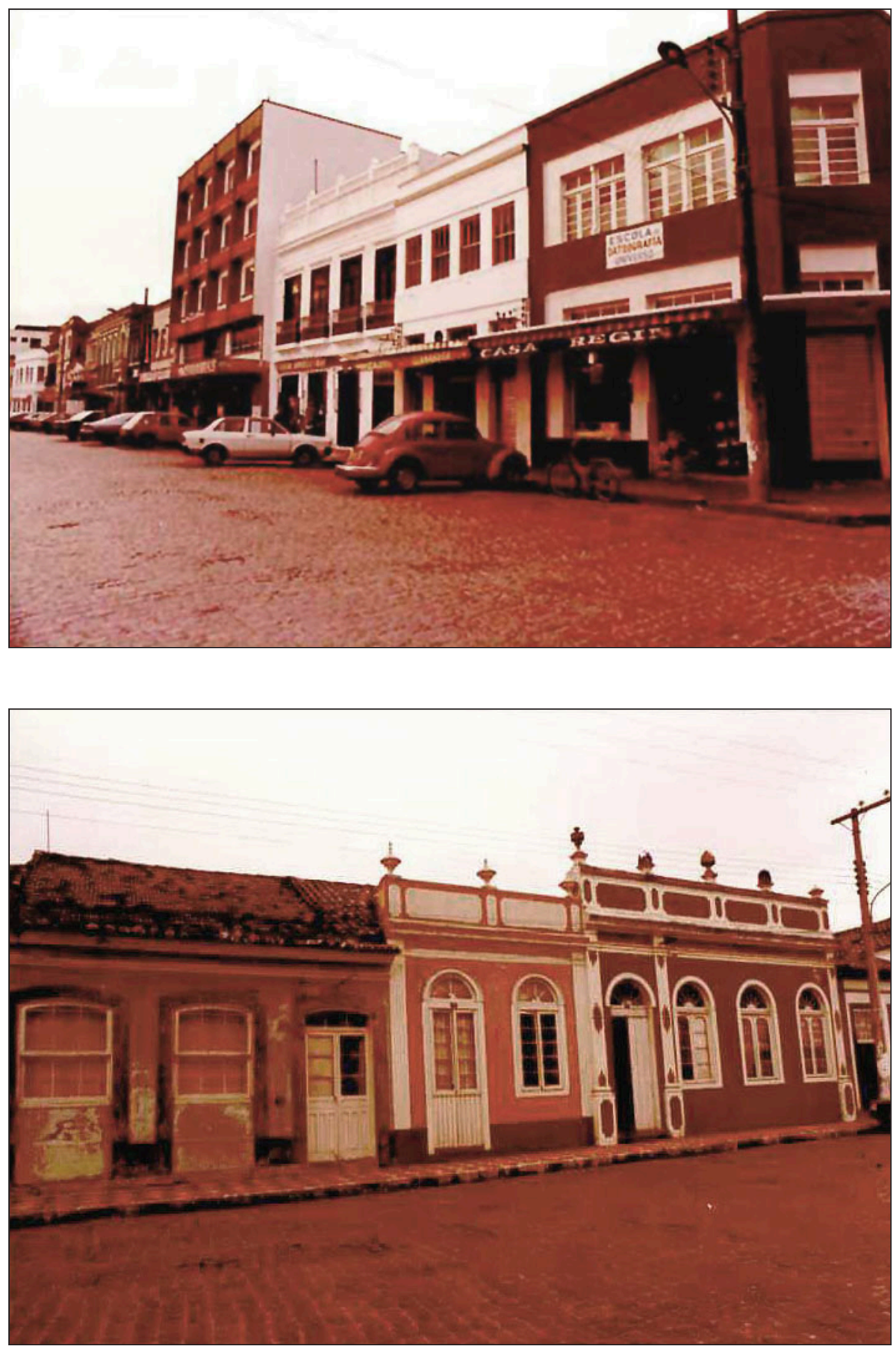

Figuras 4 (acima) e 5: Aspectos da arquitetura do Centro Histórico de Laguna à época do tombamento federal. Fonte: Iphan (1984). Apenso II do Processo de Tombamento n. $1122-T-84$

Interessante observar que a argumentação pela história dos eventos (factual e narrativa) para justificar o tombamento da cidade havia sido anunciada no ofício do prefeito de Laguna com o pedido de preservação. Sua preocupação era evidenciar a importância da cidade no contexto nacional para 
[... impedir o desaparecimento do mais rico conjunto urbano existente no Sul do Brasil com implicações históricas profundas no contexto nacional tais como a passagem do sul meridiano de Tordesilhas, núcleo de expansão rumo ao atual território do Rio Grande do Sul, sede da República Juliana, berço de Anita Garibaldi, testemunho vivo da passagem pelo Brasil de José Garibaldi. (INSTITUTO..., 1984g, p. 11)

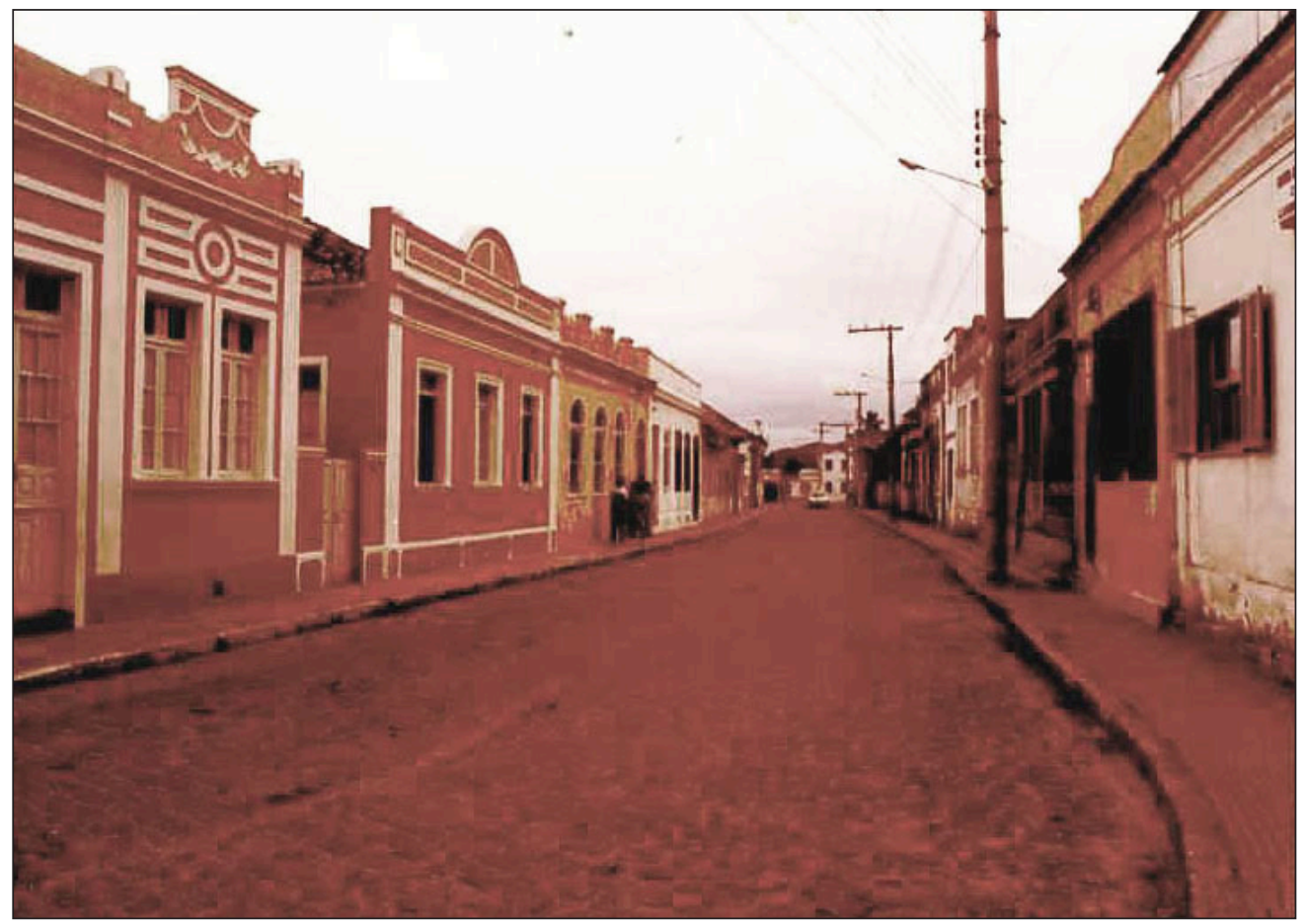

Figura 6: Aspectos da arquitetura do Centro Histórico de Laguna à época do tombamento federal. Fonte: Iphan (1984). Apenso II do Processo de Tombamento n. 11 22-T-84

A proposta de pensar a cidade inteira e não de um só edifício como "fatos memoráveis" da história indicava um caminho possível para o estudo de tombamento, amparado pelo Decreto-lei n² $5 / 37$, em que constitui patrimônio histórico e artístico nacional o conjunto dos bens móveis e imóveis de "vinculação a fatos memoráveis da história do Brasil" ou de valores excepcionais. Mas a opção do estudo de tombamento caminhou no sentido diverso: o de coadunar com uma bibliografia do campo disciplinar da história que rompe com a escrita da história a partir de eventos organizados e alinhados cronologicamente no tempo. Amparado em autores como Fernand Braudel e Marc Bloch, além dos aportes teóricos da filosofia de Benjamin, Adorno, Horkheimer e Lukács, Fernando Franco pensou a cidade de Laguna na amplitude do que a cidade poderia significar como fonte de conhecimento.

A diferença significativa, me parece, entre o pedido do prefeito e a proposta de tombamento do Iphan, ambos justificados pelo valor histórico, era a de que neste último a cidade era preservada como documento e não como fonte 
15. Segundo informações fornecidas por Lia Motta e Márcia Chuva, realizavam-se na Diretoria de Estudos e Tombamentos grupos de estudos entre os técnicos para discutir os processos e fazer leituras conjuntas, dentre as quais do arquiteto italiano Gianfranco Cannigia. Fernando Franco traduzia os textos para o português, que eram debatidos pela equipe da DET.

16. Informações fornecidas por Márcia Chuva e também disponíveis na publicação do Iphan intitulada Estudos de Tombamento deste período. Ver Instituto... (1995).

17. Para o estudo da arquitetura como documento, ver José Pessôa (2015). de conhecimento. Silvia Lara (2008) chama a atenção para essa diferença, mostrando que os historiadores em seu ofício têm à sua disposição um conjunto alargado de documentos, dentre os quais é preciso fazer seleções para se tornarem objetos de pesquisa. Documentos transformam-se em fontes na medida em que são utilizados pelos historiadores. Se a casa de Anita Garibaldi era a prova da República Juliana na argumentação do prefeito, no estudo do Iphan, a cidade de Laguna na sua completude (sem se destacar este ou aquele monumento) poderia fazer parte da história global da ocupação do território americano e de seus processos sociais, ainda por ser contada. Preservou-se o documento para o uso como fonte às gerações futuras.

Diante do fato de que os processos da ocupação da porção sul do Brasil eram ainda pouco conhecidos, Fernando Franco opta por sugerir o tombamento de grandes porções do documento histórico - a cidade - que pudessem servir a usos futuros. $\bigcirc$ entendimento da cidade como documento terá implicação direta na operação de salvaguarda de Laguna e nos critérios seletivos do espaço intraurbano. O que preservar da cidade? Que vestígios conteriam os processos históricos da cidade e, portanto, deveriam ser mantidos às gerações futuras como fonte de pesquisa? A proposta de tombamento preservou muito do documento: o conjunto paisagístico composto pelo sítio natural (lagoa, porto, montanhas), o traçado urbano e as edificações (volumetria, ocupação do solo e características arquitetônicas) expressavam a "evolução histórica do núcleo urbano" e por isso deveriam ser tombados na sua amplitude. ${ }^{15}$

As argumentações da preservação do documento histórico não ficaram restritas a Laguna. Elas serão aceitas e incorporadas rapidamente dentro do Iphan (ou ao menos dentre os técnicos da Diretoria de Tombamento e Conservação), que passou a usá-las na preservação das cidades de Cuiabá/MS, Natividade/GO, Pirenópolis/GO e São Francisco do Sul/SC, todas protegidas legalmente em nível federal na década de 1980 sob o pensamento da cidade como documento na lógica dos processos de ocupação do território na sua longa duração. ${ }^{16}$

Tais conceitos foram uma novidade significativa na história do patrimônio brasileiro. Mas, para além disso, foram uma ampliação da compreensão do documento, conforme pensada pelos Annales, no campo alargado da escrita da história. Uma potencialidade de compreensão da cultura material que ainda está à espera de mais desdobramentos e utilizações. ${ }^{17} \mathrm{~A}$ importância do trabalho de Laguna transcende, portanto, os limites do pensamento social e das políticas de preservação no Brasil.

A crítica argentina Marina Waisman aponta que um dos desafios da investigação em história da arquitetura e do urbanismo advém justamente da dificuldade em superar a narrativa dos eventos. Comumente, os edifícios icônicos são entendidos como fatos históricos, narrados numa sequência temporal sucessiva. A história da arquitetura de matriz europeia tradicional foi marcada pelos eventos, pela pontuação e estudo dos acontecimentos organizados linearmente. Há muita dificuldade na proposição de uma "história-problema" que 


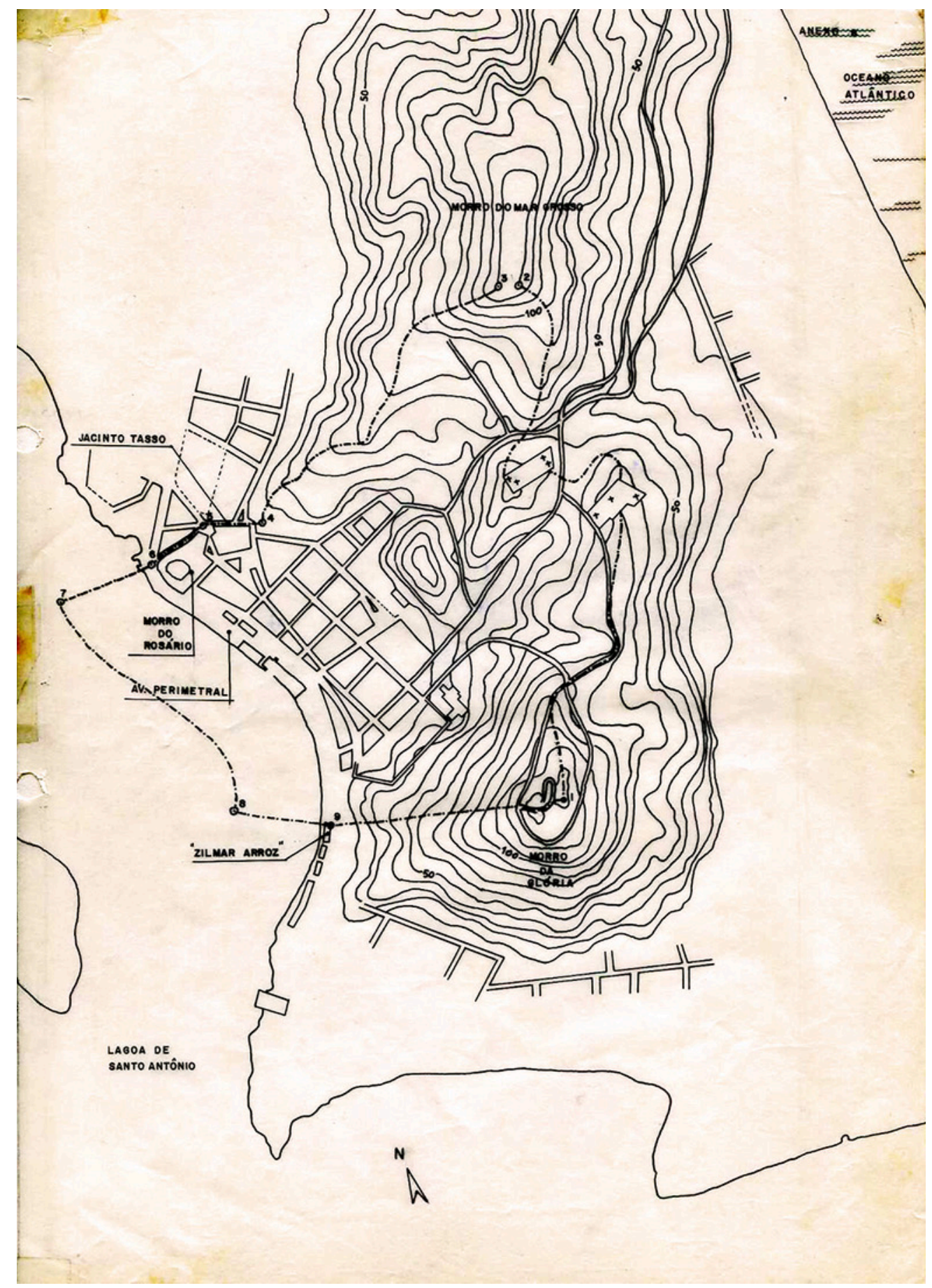

se organiza a partir das perguntas e questões que são feitas aos documentos. A história da arquitetura deveria ser capaz de "mover-se em vários planos, entrecruzando linhas de desenvolvimento, sem cair, em momento algum, na narração linear única" (WAISMAN, 2013 ).
Figura 7: Poligonal de Tombamento do Centro Histórico de Laguna pelo Iphan, conforme o Processo n. $1122-T-84$. Fonte: Iphan (1984). 
No campo da história da arquitetura e do urbanismo, a presença dos objetos coloca outra sorte de problemas à pesquisa, uma vez que a possibilidade do contato com os objetos materiais (os documentos) muitas vezes direciona as escolhas de pesquisa, levando à concentração do foco nelas mesmas. O imediatismo do conhecimento do objeto histórico dado pela presença dos edifícios e/ou da cidade pode nublar outras instâncias, como a do projeto, a da obra e a da passagem no tempo nesses mesmos objetos. Compreender a cidade e a arquitetura sob a ótica da apropriação social pelo homem possibilitaria ampliar os domínios da história da especialidade, rompendo com endogenias do campo disciplinar. Superar a autorreferência ajudaria a colocar novos problemas e perguntas aos objetos já conhecidos, evitando-se incorrer na história "de uma coisa só". Afinal, as coisas materiais não são uma parcela reificada dos fenômenos históricos (MENESES, 1985).

Parece-nos que para entender a arquitetura como fonte histórica, é interessante retomar o conceito de documento/monumento de Le Goff. Ao propor que todo documento é um monumento, o historiador aponta que ele não se separa da sociedade que o produziu, mas antes, é produto de suas ações e da passagem do tempo na sua existência. E a crítica a ele como fonte deve compreender o seu papel de rememoração no presente. Mesmo sem citar Le Goff, Luiz Fernando Franco, ao pensar na cidade de Laguna como documento, tomará parte naquilo que se chamou "revolução documental" realizada pela historiografia dos Annales. Nesse caso, a cidade era potencialmente o documento para se conhecer a ocupação do território nacional.

Ulpiano Bezerra de Meneses (2003) chama atenção para o uso ainda restrito com que as fontes visuais e a cultura material têm sido utilizadas pelos historiadores. A história tem se colocado à margem dos esforços feitos por outros campos disciplinares, como a Antropologia, do uso cognitivo da esfera da visualidade. Uma exceção seria o universo da fotografia, onde há usos consistentes da crítica à imagem como documento, absorvendo a problemática teórico-conceitual da imagem, além de estar atenta às dimensões sociais e históricas da sua história. Nas demais manifestações visuais, seu uso pelos historiadores permanece restrito ao da mera ilustração, alheio às questões teóricas da representação e à natureza da imagem visual e da visualidade, ou como repositório de informação em empírica. De modo correlato, a cultura material como categoria de análise ainda é de uso restrito entre os historiadores. Comumente, os objetos são marginalizados no horizonte mais amplo ou, são utilizados, tal como nas fontes visuais, para ilustrar aquilo que os documentos textuais já haviam apontado.

A possibilidade de romper com a perspectiva estritamente visual, fachadística ou das características estilísticas para a preservação de bens culturais a partir dos conceitos da cidade como documento, estruturados nos anos 1980 e dos quais Laguna é ponto-chave, remanesce como possibilidade conceitual a ser explorada. Tais elaborações do patrimônio enquanto documento 
acabaram por ser suplantadas ou, ao menos, obscurecidas nos anos 1990. A apropriação cenográfica dos espaços urbanos desconsiderou as práticas de preservação calcadas na historiografia da cultura, as quais criaram "as bases para o reconhecimento da história de cada localidade, independentemente do julgamento de suas características arquitetônicas, visuais, estéticas ou estilísticas" (MOTTA, 2000b, p. 259). Se o legado prático foi restrito face ao potencial teórico que o conceito de cidade como documento apresentava, parece-nos que o legado conceitual possibilitaria ainda aportes teóricos ao campo disciplinar da história da arquitetura e da urbanização, e, quem sabe, nos seus desdobramentos à preservação.

\section{REFERÊNCIAS}

BLOCH, Marc. A apologia da história, ou, O ofício do historiador. Rio de Janeiro: Zahar, 2001.

BURKE, Peter. A Escola dos Annales (1929-1989): a Revolução Francesa da historiografia. São Paulo: Ed. Unesp, 1997.

CAMPOFIORITO, Ítalo. Muda o mundo do patrimônio. Revista do Brasil, n. 4. Rio de Janeiro: Secretaria de Estado de Ciência e Cultura; Rioarte, 1985.

. O tombamento é um santo remédio. Revista do Brasil, n. 1. Rio de Janeiro: Secretaria de Estado de Ciência e Cultura; Rioarte, 1984.

CAPELATO, Maria Helena; GLEZER, Raquel; FERLINI, Vera. Escola uspiana de História. Estudos Avançados, v. 8, n. 22, São Paulo, set./dez. 1994.

CARTA de Veneza, 1964. In: CURY, Isabelle (Org.). Cartas patrimoniais. 3. ed. Rio de Janeiro: Iphan, 2004.

CERÁVOLO, Ana Lúcia. Interpretações do patrimônio. Arquitetura e urbanismo na constituição de uma cultura de intervenção no Brasil, 1930-1960. São Carlos: EdUFSCAR, 2013.

CHOAY, Françoise. A alegoria do patrimônio. São Paulo: Ed. Unesp, 2001.

CHUVA, Márcia Regina Romeiro. Os arquitetos da memória: sociogênese das práticas de preservação do patrimônio cultural no Brasil (anos 1930-1940). Rio de Janeiro: Editora UFRJ, 2009.

. O oficio do historiador: sobre ética e patrimônio cultural. In: OFICINA DE PESQUISA: A PESQUISA HISTÓRICA NO IPHAN, 1, 2008, Rio de Janeiro. Anais... Rio de Janeiro: Iphan/ Copedoc, 2008. 
Fundando a nação: a representação de um Brasil barroco, moderno e civilizado. Topoi, v. 4, n. 7, p. 313-333, jul./dez. 2003.

CONGRESSO Internacional de Arquitetos e Técnicos em Monumentos Históricos, 2., 1964, Veneza. Relatório da delegação brasileira. Veneza, 31 maio 1964.

CORREA, Sandra. O Programa de Cidades Históricas (PCH): por uma política integrada de preservação do patrimônio cultural - 1973/1979. 2012. Dissertação (Mestrado) - Programa de Pós-Graduação em Arquitetura e Urbanismo da Universidade de Brasília, Brasília, 2012.

COSTA, Lucio. Documentação necessária, 1937. In: Paulo: Empresa das Artes, 1995. Registro de uma vivência. São Depoimento de um arquiteto carioca, 1951. In: Registro de uma vivência. São Paulo: Empresa das Artes, 1995. Depoimento, 1948. In: Registro de uma vivência. São Paulo: Empresa das Artes, 1995.

CURY, Isabelle (Org.). Cartas patrimoniais. 3. ed. Rio de Janeiro: Iphan, 2004.

D’ALESSIO, Márcia. Os Annales no Brasil: algumas reflexões. Revista Anos 90, Porto Alegre, v. 2, p. 127-142, 1994.

FEBVRE, Lucien. Combates pela história. 3. ed. Lisboa: Editorial Presença, 1989.

FERREIRA, Marieta. A bistória como ofício: a constituição de um campo disciplinar. Rio de Janeiro: FGV, 2013.

FONSECA, Cecilia L. O patrimônio em processo: trajetória da política federal de preservação no Brasil. Rio de Janeiro: UFRJ/Iphan, 1997.

GONÇALVES, José Reginaldo. A retórica da perda. Os discursos do patrimônio cultural no Brasil. Rio de Janeiro: Ed. UFRJ/ Iphan, 1996.

INSTITUTO DO PATRIMÔNIO HISTÓRICO E ARTÍSTICO NACIONAL. Centro Histórico de Iguape /SP. Dossiê de tombamento. São Paulo: Superintendência do Iphan em SP, 2009.

Estudos de tombamento. Rio de Janeiro: Iphan/Departamento de Promoção, 1995.

Ata da $111^{\mathrm{a}}$ Reunião Ordinária do Conselho Consultivo do Patrimônio Histórico e Artístico Nacional, Curitiba. 27 nov. 1984a.

Avaliação Histórica, Márcia Chuva, Setor de Tombamento DTC/SPHAN. 1984b.

Informação n. 107/84 de Luiz Fernando Franco a Dora Alcântara. 1984c.

Informação n. 160/84 de Cyro Lyra a Irapoan Lyra. 1984d.

Ofício de Augusto Silva Telles ao prefeito municipal de Laguna, 6 ago. 1984e. 
Ofício de João Gualberto Pereira, Prefeito Municipal de Laguna/SC a Julio Curtis, Diretor da 10a. Diretoria Regional do Iphan. Rio de Janeiro: Arquivo Central do Iphan, $1984 \mathrm{f}$.

Ofício n.132 de 2 jul.1984 de João Gualberto Pereira e Munir Soares de Souza ao presidente da Fundação Nacional Pró-Memória. 1984g.

Ofício do prefeito de Laguna e do secretário de Cultura, Turismo e Esporte de Laguna à secretária de Educação Esther Figueiredo Ferraz. 1984h.

Processo de tombamento n. 1122-T-84. Centro Histórico de Laguna. Rio de Janeiro: Iphan, 1984 i.

. Telegrama de Joaquim da Luz a Marcos Villaça. 1984j.

Telegrama de Júlio Curtis a Augusto da Silva Telles. 28 jun. 1984k.

KNAUSS, P. O desafio de fazer história com imagens: arte e cultura visual. ArtCultura, Uberlândia, v. 8, n. 12, p. 97-115, jan.-jun. 2006.

KÜHL, Beatriz Mugayar. Notas sobre a Carta de Veneza. Anais do Museu Paulista, v. 18, n. 2, jul./dez. 2010.

LARA, Silvia Hunold. Os documentos textuais e as fontes do conhecimento histórico. Anos 90. Porto Alegre, v. 15, n. 28, p. 17-39, dez. 2008.

LE GOFF, J. Documento/Monumento. In: História e memória. Campinas: Editora da Unicamp, 2003.

LIRA, José Tavares Correia de. Arquitetura, historiografia e crítica operativa nos anos 1960. In: SEGRE, Roberto et al. Arquitetura+arte+cidade: um debate internacional. Rio de Janeiro: Viana \& Mosley, 2010.

MAGAlHÃES, Aloísio. E Triunfo? A questão dos bens culturais no Brasil. Rio de Janeiro: Nova Fronteira; Brasília: Fundação Pró-Memória, 1985.

MENESES, Ulpiano Toledo B. de. Fontes visuais, cultura visual, História visual. Balanço provisório, propostas cautelares. Revista Brasileira de História, São Paulo, v. 23, n. 45, p. 1136, 2003.

A cultura material no estudo das sociedades antigas. Revista de História, São Paulo, n. 115 , p. $103-117,1985$.

MOTTA, Lia. Patrimônio urbano e memória social: práticas discursivas e seletivas de preservação cultural, 1975 a 1990. Dissertação (Mestrado) - Memória Social e Documento, Universidade Federal do Estado do Rio de Janeiro, Rio de Janeiro, 2000a.

A apropriação do patrimônio urbano: do estético-estilístico nacional ao consumo visual global. In: ARANTES, Antônio. O espaço da diferença. Campinas: Papirus, 2000b. p. 256-287. 
MILLET, Vera. A teimosia das pedras: um estudo sobre a preservação do patrimônio ambiental no Brasil. Olinda, PE: Prefeitura de Olinda, 1988.

NASCIMENTO, Flávia Brito do. Blocos de memórias: habitação social, arquitetura moderna e patrimônio cultural. São Paulo: Edusp/Fapesp, 2016.

. Formar e questionar? Os cursos de especialização em patrimônio cultural na década de 1970. Anais do Museu Paulista, São Paulo, v. 24, n. 1, p. 205-236, jan.-abr. 2016 a.

; SCIFONI, Simone. O tombamento de Iguape como patrimônio nacional: novas práticas e políticas de preservação. PARC: Pesquisa em Arquitetura e Construção, v. 6, p. 26-38, 2015.

; MARINS, Paulo Cesar Garcez. DOSSIÊ - O PCH, Programa de Cidades Históricas: um balanço após 40 anos - Introdução. Anais do Museu Paulista, São Paulo, v. 24, n. 1, p. 11-14, jan.-abr. 2016.

PEREIRA, Júlia Wagner. Nem heroico nem moderno: a constituição do "Patrimônio Histórico Artístico Nacional" gestão de Renato Soeiro no Iphan (1967-1979). In: INSTITUTO DO PATRIMÔNIO HISTÓRICO E ARTÍSTICO NACIONAL. Programa de Especialização em Patrimônio - Artigos (2005 e 2006). Rio de Janeiro: Iphan/ Copedoc, 2009a.

PESSÔA, José (Org.). Lucio Costa: documentos de trabalho. Rio de Janeiro: Iphan, 1999.

A arquitetura como documento. In: ROSSA, Walter; RIBEIRO, Walter. Patrimônios de origem portuguesa: modos de olhar. Niterói: Eduff; Lisboa: Calouste Gulbenkian, 2015.

REIS, José Carlos. O desafio bistoriográfico. Rio de Janeiro: Editora FGV, 2010.

ROCHA-PEIXOTO, Gustavo. Inepac - Um perfil dos 25 anos de preservação do patrimônio cultural no Estado do Rio de Janeiro. Arquitetura Revista, Rio de Janeiro, n. 8, v. 8, FAU/UFRJ, 1990.

RODRIGUES, Marly. Imagens do passado: a instituição do patrimônio em São Paulo, 19691987. São Paulo: Unesp/Imprensa Oficial do Estado/Condephaat/Fapesp, 2000.

ROIZ, Diogo; SANTOS, Rafael. As transferências culturais na bistoriografia brasileira: leituras e apropriações do movimento dos Annales no Brasil. Jundiaí: Paco Editorial, 2012.

RUBINO, Silvana. O mapa do Brasil passado. Revista do Serviço do Patrimônio Histórico e Artístico Nacional, Rio de Janeiro, n. 24, p. 97-105, 1996.

As fachadas da história: os antecedentes, a criação e os trabalhos do SPHAN, 19371991. 1991. Dissertação (Mestrado) - Departamento de Antropologia. Campinas, 1991.

SANT'ANNA, Márcia. Da cidade-monumento à cidade documento. A trajetória da norma de preservação de áreas urbanas no Brasil (1937-1990). Dissertação (Mestrado) - Faculdade de Arquitetura e Urbanismo, Universidade Federal da Bahia, Salvador, 1995. Mimeo.

A cidade-atração: a norma de preservação dos centros urbanos no Brasil dos anos 90. Tese (Doutorado) - Faculdade de Arquitetura e Urbanismo, Universidade Federal da Bahia, Salvador, 2004. 
SANTOS, Mariza Veloso. Nasce a academia SPHAN. Revista do Patrimônio Histórico e Artístico Nacional, Rio de Janeiro, n. 24, 1996.

SMITH, Laurajane. Uses of heritage. New York: Routledge, 2006.

TELlES, Augusto da Silva. Ementa da disciplina Teoria da Conservação. Curso de Restauração e Conservação de Monumentos e Conjuntos Urbanos. Convênio Seplan/Iphan/UFPE. Rio de Janeiro: Arquivo Central do Iphan, 1976.

THOMPSON, Analucia (Org.). Entrevista com Judith Martins. Rio de Janeiro: Iphan/DAF/ Copedoc, 2009.

TOURNIKIOTIS, Panayotis. The histography of modern architecture. Cambridge: The MIT Press, 1999.

WAISMAN, Marina. O interior da história: historiografia arquitetônica para uso de latinoamericanos. São Paulo: Perspectiva, 2013

Artigo apresentado em 28/03/2016. Aprovado em 28/12/2016. 